\title{
Learner Motivation From a Teacher Perspective
}

\section{Robert J. Watson \\ British Council, Japan.}

\section{Reference Data:}

Watson, R. J. (2020). Learner motivation from a teacher perspective. In P. Clements, A. Krause, \& R. Gentry (Eds.), Teacher efficacy, learner agency. Tokyo: JALT.

https://doi.org/10.37546/JALTPCP2019-19

This paper is an investigation of teachers' perceptions of motivating and demotivating influences on students at a private university in Japan. It focuses on teachers' views of students' motivation on a three-year compulsory English course for Economics students, with the aim of increasing understanding of learner motivation and applying this to the improvement of teaching methods and course design. Qualitative data, represented in pie charts, is used in the form of semi-formal interviews with teachers of the program. Findings suggest that an interesting and communicative lesson environment is motivating for students in combination with regular assessment. In relation to this, teachers should approach classes from their learners' perspective and consider personalisation of materials. They should also be aware that students' motivation is boosted when teachers show a genuine interest in students and provide positive feedback and explanations of the rationale and value of activities.

本論は、日本の私立大学で学生のモチベーションを教師が理解することにより出る影響の調査である。三年間英語を必修 科目として学んだ経済学部の学生達のモチベーションを教師の立場から理解し、教授法、コースデザインの改良に焦点をあで た。円グラフで表した定性データは、半公式的に教師陣にインタビューしたものである。面白く、話しやすい環境を作ることが、 学生のモチベーションと正確な評価につながることがわかった。そのため教師は、学生の立場から彼らに合った教材を選ぶこ が、学生達のモチべーションを押し上げるということに気づいておくべきである。

$\mathrm{n}$ any field of learning, the importance of motivation to successful outcomes is clear. The experience of failing at a new endeavour, despite initial intentions, due to motivational issues is mostly common (Minnaert, 1999; Weiner, 2001). This is particularly clear in the field of language teaching where the effects of motivation can often be very marked on language learners. In fact, Brown (2007) states "motivation is a star player in the cast assigned to language learning around the world" (p. 168).

In Japan, research in both school and university contexts show motivational issues such as disciplinary problems, lack of attention, and even sleeping in class as commonplace issues for English teachers (Nakata, 1999; Tatsumoto, 2010). While it can be difficult to ascertain for what reasons these problems arise, Sakui and Cowie (2012) suggest that harnessing motivation in this context is extremely relevant, and the significance of motivation for success in language learning should not be underestimated.

This paper focuses on understanding learner motivation from the perspective of teachers in a private university in Japan. Through semi-structured interviews conducted with teachers working on the same program, teachers' views of learner motivation in this context were gathered and analysed. Based on the analysis, an approach to motivation in this environment was formulated.

\section{Literature Review}

Considering the teacher's behaviour as paramount in the motivation of learners can be seen in the work of Dörnyei and Csizer (1998) and the creation of ten commandments for motivating language learners. This was produced following a survey of 200 English teachers in Hungary, who were asked to rank 51 motivational strategies according to importance. The results were then used to select the 10 most popular factors. The ten commandments included areas related to classroom management, such as presenting tasks properly, increasing self-confidence, and setting a personal example. In addition, strategies related to improving learner interest were incorporated: making classes interesting by personalising language processes and by setting a context that is familiar to the learner, easy to envisage, and which they can relate to. Finally, the importance 
of learner and teacher rapport was highlighted by factors such as developing a good relationship with learners and creating a relaxed environment for learning.

Considering the role of teachers further, Dörnyei (2001) suggested a four-stage approach by teachers towards motivation. First, by listening to students, committing to their expectations, and showing enthusiasm, teachers can create conditions for motivation. Following the creation of conditions for motivation, motivation can then be generated in three different ways. One option is by intrinsic motivation, which focuses on satisfaction gained from learning and achieving. Another is by integrative motivation, for example, by considering the importance of cultural exchange with other countries. The final method is the use of instrumental motivation by seeing the practical benefits that can be achieved by learning. An expectation of success at this stage for learners will also help to generate this motivation. The third stage of this approach is to maintain and protect motivation. An avoidance of monotony in lessons, a variety of tasks, and adequate consideration of learners' selfesteem and anxiety about language will lead to motivation being protected. The final stage of the process is one of reflection and evaluation. Learners' perceptions of achievements or failures often have a bearing on motivation. Dörnyei (2001) therefore suggests that teachers should promote determination rather than capacity and provide motivational feedback on strengths, progress, and accomplishments, with tangible strategies on areas for improvement.

A third area of research related to teachers' effect on learner motivation is the work of Reeve (2016) and the theory of autonomy-supportive teaching. This suggested fostering a student-teacher relationship based on autonomy and encouraged teachers to be "in synch" (Reeve, 2016, p. 133) with their students, where the actions of one influence the other. The idea of understanding learners better, personalising materials to meet their needs, and explaining rationales behind actions are concepts that most would agree should be practiced in any modern learning situation. However, at times it could be argued that some aspects of autonomy-supportive teaching may be unrealistic in the study's context within universities in Japan. For example, the requirement that teachers use patience, wait for involvement, and strive for total learner autonomy may not match a mandatory learning environment with relatively immature learners. Indeed, Cowie and Sakui (2012) state that a realistic approach to the limitations of motivation is necessary, particularly in relation to intrinsic motivation, which maybe unachievable on a day-to-day basis. The work of Sakai and Kikuchi (2009) suggests that a wide range of other factors, such as textbooks, course contents, and test scores can also affect learner motivation and should also be considered in addition to factors which are controlled by teachers.
A wider consideration of other factors that affect learners' motivation and teachers' perception of these can be seen in the previously referenced work of Cowie and Sakui (2012). This study revealed three areas in which teachers felt limited in motivating students: institutional systems, students' attitudes and personalities, and teacherstudent relationships. Furthermore, they suggested three ways in which to remedy these The first way is by focusing on relationships with students, taking a personal interest in them, getting to know their interests, and personalising lessons. The second is by setting clear goals. This should be a clear sequence of activities that supports the outcomes of lessons and includes the teacher monitoring students' progress and providing them with feedback. The final way is by creating lessons of a high quality by modelling enthusiasm and effort. This includes enriching the classroom experience by creating relevant and thought-provoking lessons with varied and stimulating materials.

Purpose of the Study

The views presented by the ten commandments (Dörnyei \& Csizer, 1998) and autonomysupportive teaching (Reeve, 2016) provide an appropriate point of comparison when interviewing teachers for this study and examining what they consider as important in motivating their learners. In addition, the studies by Sakai and Kikuchi (2009) offer information about what could be significant to learner motivation in a context similar to the one in this research and outline contextual factors, which could also affect learner motivation. Finally, the work of Cowie and Sakui (2012) shows areas limiting learner motivation according to English teachers in Japanese universities, and approaches which teachers can take to remedy these. These areas and approaches can be compared to the views of teachers in this research to conclude that their approach to motivation is relevant to this study.

\section{Context}

This study took place in a private university in Japan, with campuses in Tokyo and Yokohama. It focused on a compulsory English for Communication course, which was taught within the Economics Faculty of the university.

\section{Research Questions}

1. According to teachers, what factors support learners' motivation to study English? 
2. According to teachers, what factors hinder learners' motivation to study English?

3. What implications do the above have on course design and teachers approaches?

\section{Participants}

For this research, five teachers were interviewed. The reason for this selection was that these five teachers, in addition to the writer, are responsible for all the compulsory English courses offered to the Economics Faculty. The background of the teachers is fairly homogenous. All five teachers speak English as their first language, four out of the five teachers are male and four out of the five are from the UK, with one teacher from Canada. The teachers' experience range from one year to over fifteen years and their qualifications range from CELTA to postgraduate qualifications. Though a wider range of teacher backgrounds may have been desirable, this researcher's goal was to ascertain the views of the teachers of this department on learner motivation and consider how learner motivation can be improved within this department; interviewing teachers from a broader background could have undermined this.

Prior to conducting the interviews, participants were asked to sign a consent form to understand the contents and rationale of the interviews and observe ethical considerations. Following these explanations, all participants agreed to take part in the interviews.

\section{Research Methodology}

As previously stated, this study used qualitative methods within the interpretive paradigm (Hatch, 2002), in the form of teacher interviews, as the data collection source. Interviews were carried out with the five teachers individually. They followed the format of a semi-structured interview. Questions were prepared and open-ended. Unscripted follow-up questions were asked, and teachers were asked to elaborate their responses. This method was selected as a means of gathering qualitative data because it allows for some control of the process. However, as it is not a standardised interview with completely determined data and systematic procedures, it can also allow ideas to emerge through the interviewing (Hatch, 2002). The interview process took place in a constructivist tradition: working with the interviewers to reconstruct and make sense of the findings and sharing the findings with those involved to lead to better practice in the future (Hatch, 2002). The interviews lasted around 45 minutes to an hour and took place in a pre-booked classroom on the university campus.

\section{Interview Contents}

The rationale for the interview questions was shaped from five different areas (A-E, see below). These emerged from the literature review and the original aims of the study. The main areas are summarised below.

A. The teacher's personal views of motivation and how these contrast with literature in the field.

B. Motivational factors connected to the teaching context i.e. within a Japanese University and with learners whose English experience comes from the Japanese education system.

C. The teacher's role in motivating learners, with consideration of the Dörnyei (2001) four-step model.

D. The teacher's role in motivation based on Reeve (2016) and Dörnyei and Csizer's (1998) ten commandments.

E. Implications of teacher's views and approaches on motivation to design a course. The interview questions are provided in the Appendix.

\section{Findings}

Interviews were carried out over a four-week period in the participants' workplaces. The responses were coded using a typological analysis method, where analysis commenced from dividing data into predetermined categories based upon theory in the field and the research objectives (Hatch, 2002), which were then used with the goal of trying to find patterns of responses in the interviews (Saldana, 2016). Analysis resulted in selecting the following four themes for coding.

A. Motivating factors for students.

B. Demotivating factors for students.

C. Factors related to context of study and students.

D. Teachers' behaviours.

It was decided that these themes would be used rather than the format of the initial interview as these related better to the goals of the research. 
After the themes had been chosen, the transcripts were initially coded for ideas that could be attributed to these themes, and these were recorded in note form. However, due to the amount of responses that emerged, it was decided that in the second round of coding, a response would only be coded and logged if it was mentioned three times or more. The coded areas can be seen in the following two tables.

Table 1. Motivating and Demotivating Factors for Students

\begin{tabular}{|c|c|}
\hline $\begin{array}{l}\text { A. Motivating factors for students } \\
\text { ( } 3 \text { mentions or more) }\end{array}$ & $\begin{array}{l}\text { B. Demotivating Factors } \\
\text { ( } 3 \text { mentions or more) }\end{array}$ \\
\hline $\begin{array}{ll}\text { 1. } & \text { Interesting } \\
\text { 2. } & \text { Arouse curiosity } \\
\text { 3. } & \text { Relevance } \\
\text { 4. } & \text { Pace and Flow } \\
\text { 5. Praise } \\
\text { 6. Tests } \\
\text { 7. Incentives } \\
\text { 8. Fun } \\
\text { 9. Realisation of progress } \\
\text { 10. } \text { Communicative } \\
\text { 11. Goals } \\
\text { 12. Rationale or Reason } \\
\text { 13. } & \text { Pair or Group Work }\end{array}$ & $\begin{array}{l}\text { 1. Teacher Centred } \\
\text { 2. Lack of rationales } \\
\text { 3. Too much choice } \\
\text { 4. Textbook } \\
\text { 5. Language/Grammar activities } \\
\text { 6. External factors (e.g., time of day/ } \\
\text { point in semester) }\end{array}$ \\
\hline
\end{tabular}

Table 2. Factors Related to Context of Study, Student and Teacher Behaviours

\begin{tabular}{|c|c|}
\hline $\begin{array}{l}\text { C. Factors related to context of study and } \\
\text { students } \\
\text { ( } 3 \text { mentions or more) }\end{array}$ & $\begin{array}{l}\text { D. Teacher behaviours } \\
\text { ( } 3 \text { mentions or more) }\end{array}$ \\
\hline 1. Fresh at start of courses & 1. View from students' perspective \\
\hline 2. Peer pressure to conform & 2. Patience \\
\hline 3. Desire to please authority figures & 3. Positive feedback \\
\hline $\begin{array}{l}\text { 4. Lack of experience of production in } \\
\text { English }\end{array}$ & $\begin{array}{l}\text { 4. Trusted by students/viewed } \\
\text { competent }\end{array}$ \\
\hline 5. Previous negative English & 5. Creating pleasant atmosphere \\
\hline experiences & 6. Noticing signs of demotivation \\
\hline 6. Rote learning experience in English & 7. Explaining values and rationales \\
\hline 7. Grammar study experience & 8. Personalising learning to students. \\
\hline 8. Lack of learner autonomy & 9. Showing flexibility \\
\hline 9. Short attention span & 10. Showing genuine interest in students \\
\hline 10. Failure to see wider reason to study & \\
\hline
\end{tabular}

\section{Results and Discussion}

For each section the results were first recorded in tables to show both individual teacher's responses and the total response. They were then recorded in the included pie charts to allow easier comparison of the coded areas and the percentage of responses. 


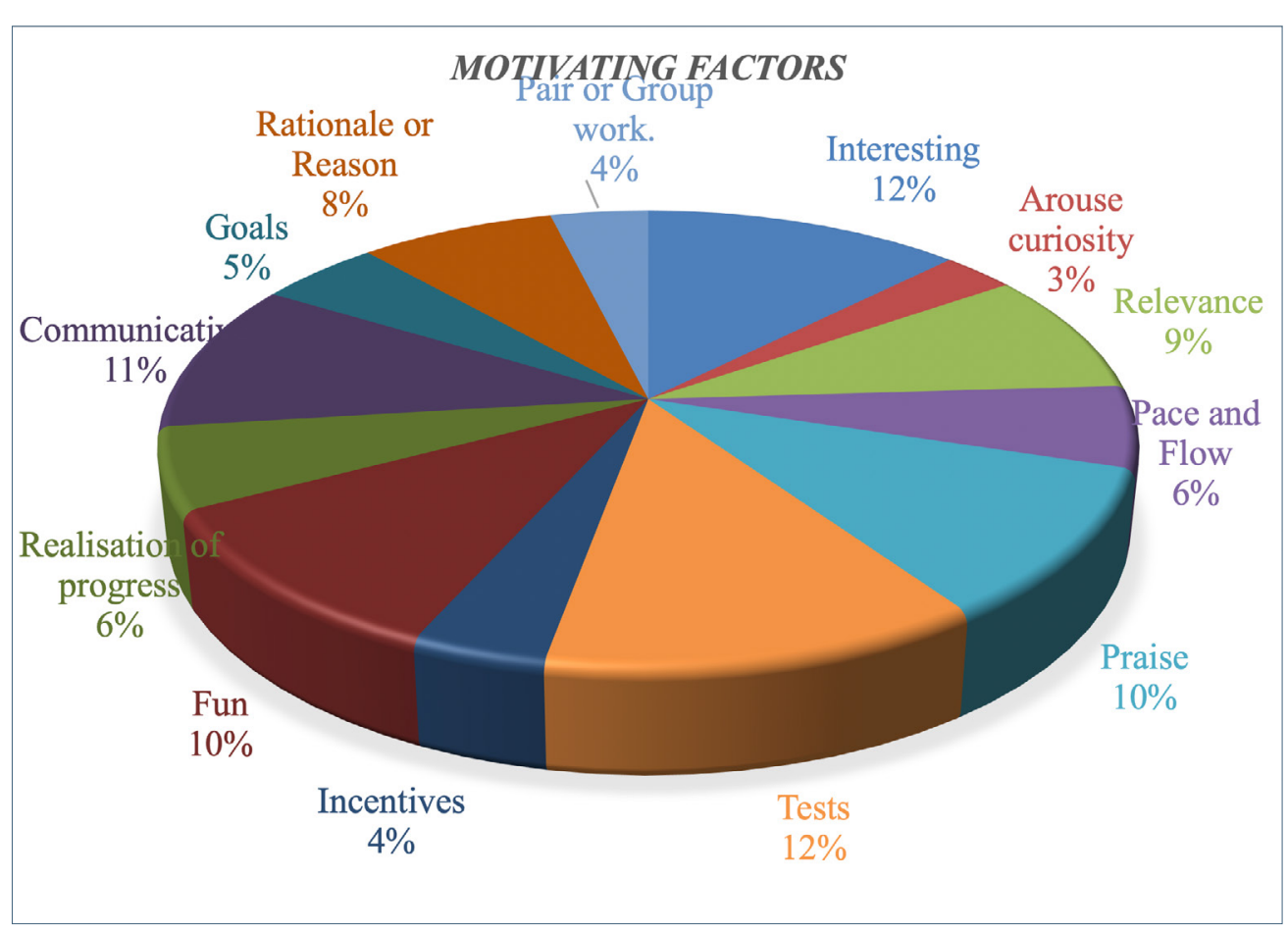

Figure 1. Responses for motivating factors for students.

In this section the total number of responses was 104. These responses were converted to percentages, with some rounding down or up within the software to allow for the total to reach $100 \%$. The same approach was used for the other four sections.

The data from this section shows five areas scoring $10 \%$ or over of the total responses. The top two were interest in lessons from the students and testing, which were both mentioned 13 times in interviews. It merits mentioning, however, that in relation to interest, 6 responses were by one teacher, while the responses were more evenly spread for tests. Following this, communicative activities, fun, and praise were all mentioned 11 times by teachers, though for fun, 6 responses came from one teacher, while the other 2 were more balanced.

It can be suggested from these results that students will be motivated when lessons are interesting to them, communicative, fun, and they are praised regularly, but these lessons must also be relevant to the tests they take, which contribute to their final grade.

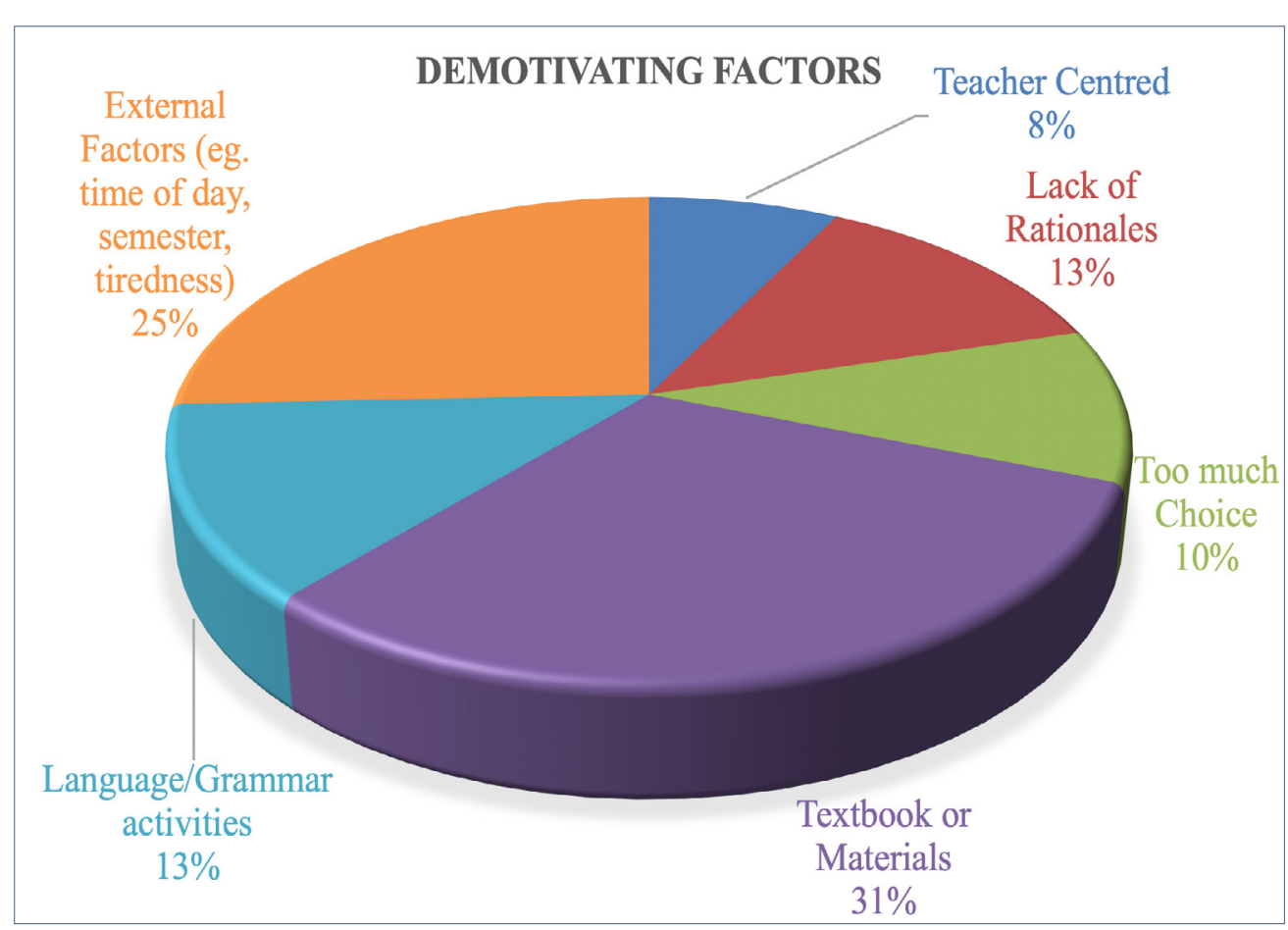

Figure 2. Responses for demotivating factors for students.

This section shows two factors as clearly more influential than others in causing learner demotivation. These were textbook or materials, which accounted for $31 \%$ of the total responses, and external factors with $25 \%$ of the total responses. Both had a reasonable distribution and were mentioned at least once by all teachers interviewed.

These factors in the data suggest that teachers should be aware of the demotivating effects of external factors, such as point in the semester or time of class, in order to try and control these and remotivate classes. In addition to this, the contents of materials, particularly textbooks, must be considered carefully when planning and delivering lessons. 


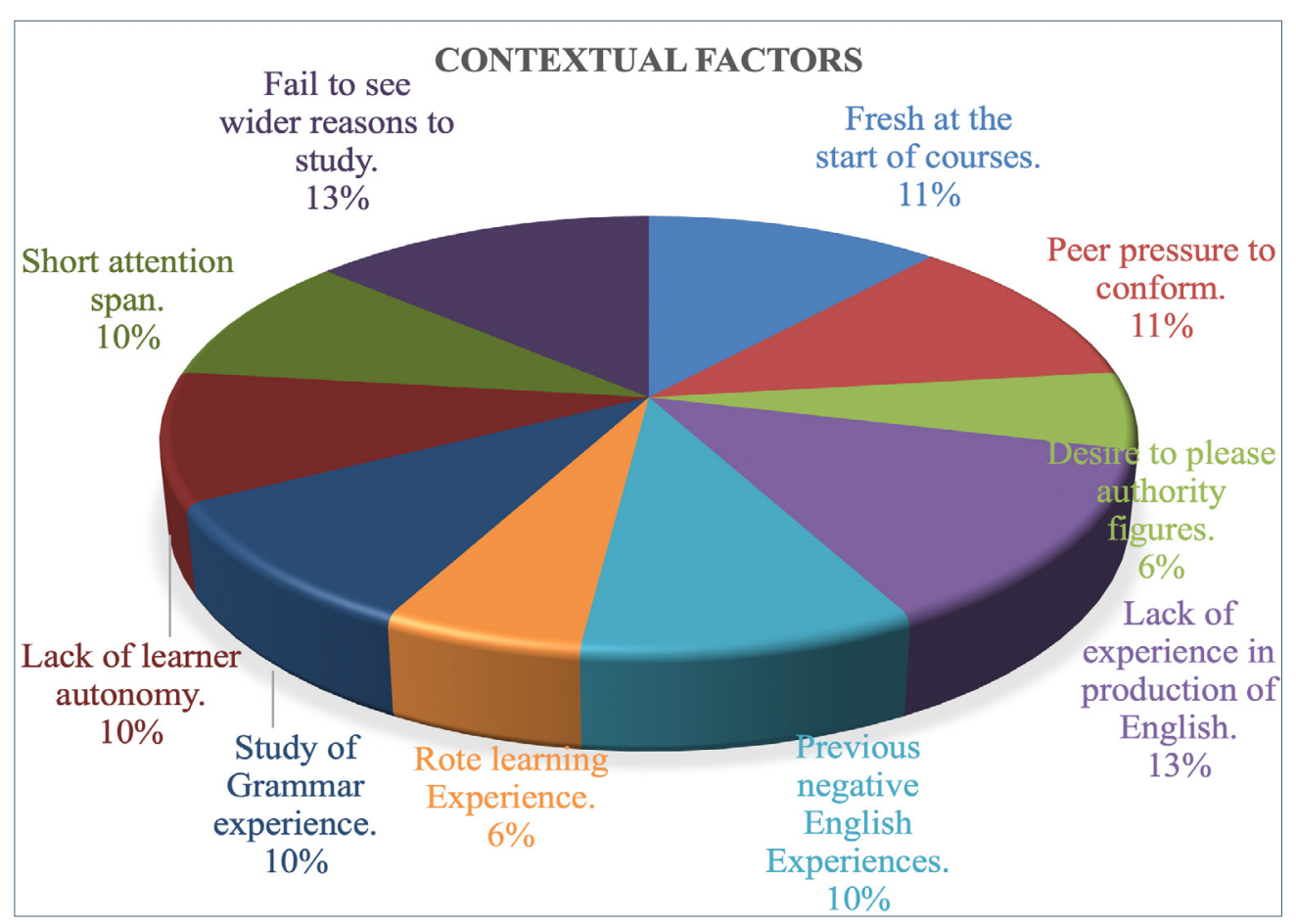

Figure 3. Responses for contextual factors.

In this section, 5 of the 10 factors mentioned received more than $10 \%$ of the total. Failure to see a wider reason to study and lack of English-speaking experience were both stated seven times with $13 \%$ of the total, while peer pressure to conform and fresh at the start of courses were mentioned six times with $11 \%$. Finally, short attention span was identified five times with $10 \%$ of responses.

These factors suggest that the most important contextual factors in need of consideration by teachers relate to students' age and current situation. They have not had many opportunities to speak English, friendship groups have a big effect on them, and their short attention span and lack of understanding of wider rationales relate to a relative lack of maturity. However, as studying English at university is a new experience, they tend to start courses with greater motivation, which if harnessed as courses continue, could be powerful.

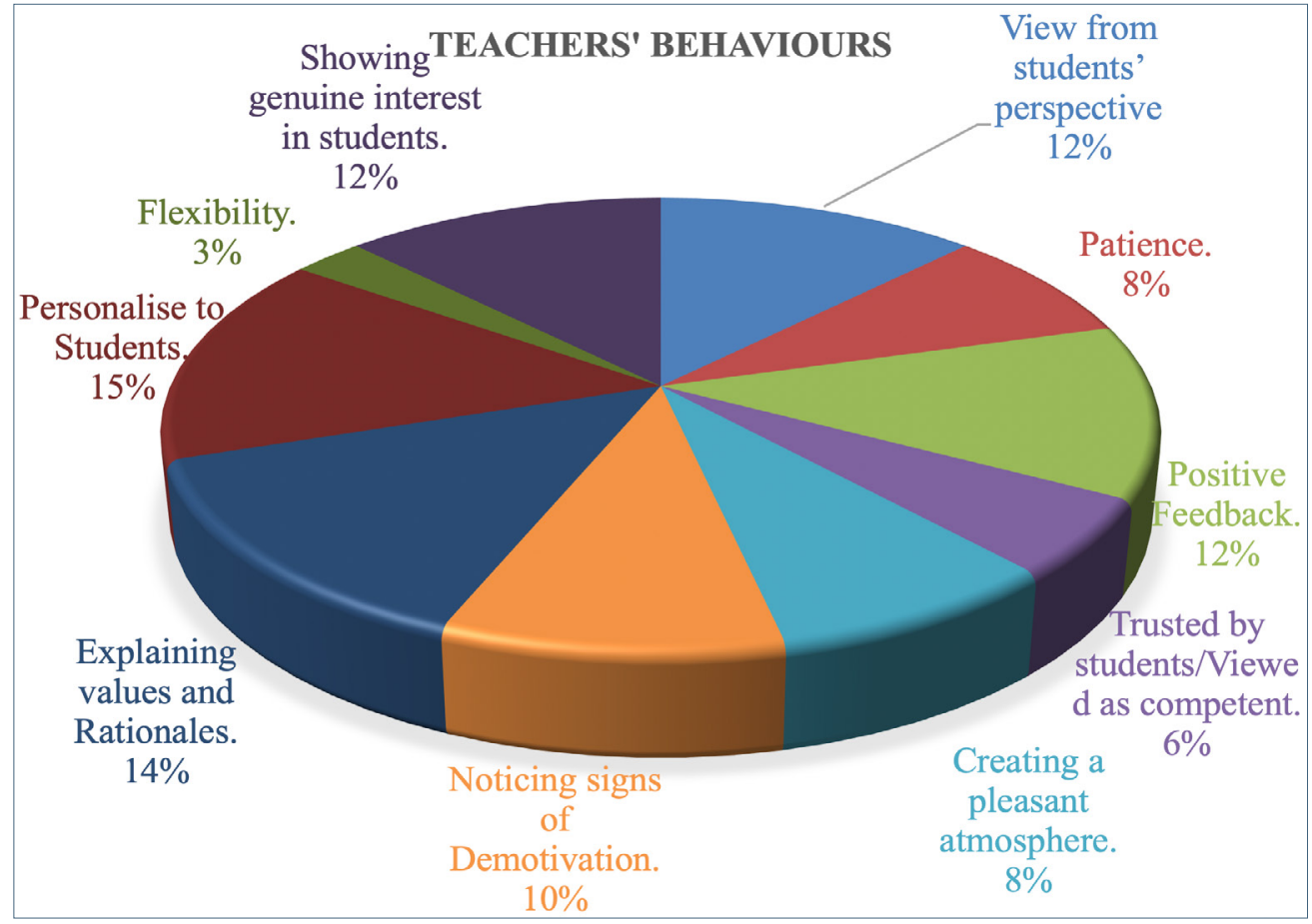

Figure 4. Responses for teachers' behaviours.

The data for teachers' behaviours has five factors achieving over $10 \%$ of responses. The most popular approach was personalise learning to students, which was stated 11 times, with an even distribution of responses between teachers, accounting for $15 \%$ of the total. Explaining values and rationales closely followed this with 10 mentions and $14 \%$ of the total. Positive feedback, a genuine interest in students, and view from students' perspective were all stated nine times with $12 \%$ of the responses. While Teacher D and $\mathrm{E}$ accounted for eight of the responses related to a genuine interest, the distribution was fairly even for the other two areas.

These factors show that teachers should consider students first in their behaviour by personalising their learning, showing interest, and considering activities from their perspective. In addition to this, explaining why an activity has been selected and why it is valuable, while giving positive feedback on students' performance, should boost motivation. 


\section{Educational Implications}

Considering the results above, a suggested approach for teachers to motivate learners in the study's context can be outlined.

\section{Motivating factors for students}

1. Lesson contents should be interesting to learners to encourage effort.

2. Communicative, fun activities show a break from traditional high school approaches to teaching English, and this difference is motivating for students.

3. Praise to boost confidence and decrease anxiety is motivating.

4. Testing is a valuable tool to create extrinsic motivation in courses.

\section{Demotivating factors for students}

1. External demotivating factors, such as time of the class, or point in the semester are inevitable. Teachers should be sensitive to these and use strategies to remotivate students when this occurs

2. Consider use of textbooks carefully. Textbooks should be adapted so that they are relevant to learners' needs and interesting to them.

\section{Contextual Factors}

1. Learners have little prior communicative experience in English. Make it a priority to build up these skills.

2. Educate students about the benefits of the study of English in a globalised world to see wider reason for study, beyond achievement in assessments.

3. Accept peer pressure and short attention spans but try to minimise them with a positive classroom environment, a fast pace, and a variety of activities.

4. Aim to maintain the positivity and motivation that students have at the start of courses.

\section{Teachers' Behaviours}

1. Good relationships with students should not be underestimated. Interest in students, considering activities from their perspective, and personalising will help students feel valued in the classroom.
2. Providing positive feedback and creating a warm environment in classes will help students to be more motivated.

3. Students need to be told why an activity has been chosen, what value this has to them, and the rationale of the activity. If they understand why, they are likely to be more motivated.

\section{Conclusion}

This research targeted the motivation of university students through the eyes of their teachers at a private university in Japan. Qualitative research methods were used, which were then coded and presented using pie charts.

It was found that while learners could be encouraged by a range of factors, the most effective motivators for them were interesting and fun activities, a communicative environment, praise from teachers, and being assessed. In contrast to this, learners tended to be demotivated most by textbooks and some teaching materials, together with external factors, such as tiredness, or the point of day the lesson was held.

In respect to contextual factors, teachers felt that a background in which learners had not used English for communicative purposes before, a failure to see the wider purpose to activities, peer pressure, and short attention spans were all factors that needed to be considered in relation to demotivation. In addition, the freshness and enthusiasm students show at the start of a university year was an opportunity that should be grasped.

Finally, regarding teacher behaviour, the research outlined the need for learnercentred, personalised lessons where teachers show interest in students, understand them from their perspective, provide positive feedback, and explain clearly the value and rationale of what occurs in the classroom.

It is hoped that this study has provided some insight into how teachers, within any English teaching context, can consider their students' desire to study English further and can try to help to motivate them more effectively in their learning. The findings also have implications related to teacher support and orientation in the context of the study, as they can provide a framework which can be used by existing teachers and when briefing new teachers about the most effective ways of motivating their students.

Limitations and Areas for Further Research

Though this study was successful in gaining insight into teachers' views on motivation within its context, there were some limitations and areas that could be researched 
further. Firstly, related to some of the data collected there was limited critique of the materials used or improvements to these. Teachers talked about the type of activities but not about specific parts of the courses or why or how the textbooks sometimes caused demotivation. This may have been to do with the format of the interview, as this area was the final question and after 30-40 minutes of discussion it was felt that enough ground had been covered. Therefore, in retrospect, it would have been better to focus on this earlier in the interviews.

Areas that could be researched further include carrying out further studies related to course design, as this was stated as a limitation in this study, and also considering widening the research significantly by including interviews with students on these courses, as clearly the students' individual views of motivation would provide significantly more depth to this research.

\section{Bio Data}

Robert Watson has worked in ELT for over 15 years, holds a masters in TESOL from the University of Birmingham and is now working for Chiba University. Correspondence related to this article should be addressed to: robwatson@chiba-u.jp

\section{References}

Brown, H. D. (2007). Principles of language learning and teaching. (5 ${ }^{\text {th }}$ ed.). White Plains, NY: Pearson Education.

Cowie, N. \& Sakui, K. (2012). Three tales of language teacher identity and student motivation. JALT Journal, 34(2), 127-151. Retrieved from https://doi.org/10.37546/jaltjj34.2-3

Dörnyei, Z. (2001). Motivational strategies in the language classroom. Cambridge: Cambridge University Press.

Dörnyei, Z. \& Csizer, K. (1998). Ten commandments for motivating language learners: Results of an empirical study. Language Teaching Research, 2(3), 203-229. Available from https://doi.org/10.1191/136216898668159830

Hatch, J. A. (2002). Doing Qualitative research in education settings. Albany, NY: State University of New York Press.

Kikuchi, K. \& Sakai, H. (2009). Japanese learners' demotivation to study English: A survey study. JALT Journal, 31(2), 183- 202. Retrieved from https://jalt-publications.org/recentpdf/jij/2009b/ art3.pdf
Minnaert, A. (1999). Motivational and emotional components affecting male's and female's selfregulated learning. European Journal of Psychology of Education, 14, 525-540. Retrieved from https://doi.org/10.1007/bf03172977

Nakata, Y. (1999). Motivation in language learning. Tokyo: Libery Press.

Reeve J. (2016) Autonomy-supportive teaching: What it is, how to do it. In W. Liu, J. Wang, \& R. Ryan (Eds.), Building autonomous learners (pp.129-152). Singapore: Springer. Available from https://doi.org/10.1007/978-981-287-630-0_7

Sakui, K. \& Cowie, N. (2012). The dark side of motivation: Teachers' perspectives on 'unmotivation.' ELT Journal, 66(2), 205-213. Retrieved from https://doi.org/10.1093/elt/ccr045

Saldana, J. (2016). Chapter 1: An introduction to codes and coding. From The coding manual for qualitative researchers ( ${ }^{\text {rd }}$ ed.). Retrieved from https://uk.sagepub.com/sites/default/files/upmbinaries/49731_Saldana_Chapter_1.pdf

Tatsumoto, M. (2010). Perceived effects of peer cooperation on motivation in the Japanese EFL classroom (Doctoral dissertation), University of Birmingham). Retrieved from http://etheses. bham.ac.uk/1758/

Weiner, B. (2001). Intrapersonal and interpersonal theories of motivation from an attribution perspective. In F. Salili, C. Y. Chiu, \& Y. Hong (Eds.), Student motivation. Plenum series on human exceptionality (pp.17-30). Boston, MA: Springer. Available from https://doi.org/10.1007/978-14615-1273-8_2

\section{Appendix}

Interview Questions

Background questions

1. Tell me a little about your background in teaching? What kinds of teaching have you done both in Japan and overseas?

2. What do you enjoy most about teaching?

Section A: This section is about your personal views on motivation and allows these to be contrasted with various views from literature and studies in the field of motivation.

1. How would you define motivation in learning a second language? (Consider this generally in addition to your current context.)

2. When your students begin courses how motivated do you think they are? What kind of motivation do they have?

3. What strategies do you use in your teaching to generate motivation in your students? 
4. What strategies do you use to maintain motivation your students already possess?

5. Tell me about a time when your students appeared particularly motivated. What do you think caused this?

6. Tell me about a time when your students appeared particularly demotivated. What do you think caused this?

Section B: This is related to motivational factors connected to the teaching context, i.e. within a university in Japan, with learners who have mostly learnt English in the Japanese Education system.

1. How far do you think students' past experiences of studying English shape their motivation for study or lack thereof?

2. In a lesson what factors can cause student demotivation? How do you try to control these factors?

Section C: This Section relates to how a teacher can motivate individual students and the responsibility of teachers related to learners' motivation.

1. How do you see a teacher's role in motivating students? Which of the following do you see as part of this role? Why?

- Generating motivation in activities in class.

- Creating an interest in English.

- Protecting the motivation a student already possesses.

- Giving feedback and evaluating students in a motivating way.

Do you see anything else being involved?

Section D: This section refers to environmental and situational factors under a teacher's control and how far these can be used to motivate.

1. Consider the following factors. Which five do you see as most relevant to a teacher's role in motivating students? Why do you think so?

- Set a personal example with your own behaviour.

- Create a pleasant, relaxed atmosphere in class.

- Present the tasks properly.
- Develop a good relationship with the learners.

- Increase the learners' linguistic self-confidence.

- Make the language classes interesting.

- Promote learner autonomy.

- Personalize the learning process.

- Increase the learners' goal-orientedness.

- Familiarize learners with the target language culture.

(From Dörnyei \& Csizer, 1998, 10 commandments)

2. Which of the factors below do you see as most relevant to motivating students? Are any of these factors irrelevant? (Please tick and explain why.)

- Taking the student's perspective

- Supporting autonomy

- Arousing curiosity

- Explaining rationales

- Identifying value

- Being flexible and open minded

- Providing choice

- Listening to students

- Acknowledging negative affects

- Accepting validity of complaints

- Allowing students to work at their own pace

- Waiting for students to take initiative

- Being patient.

(From Reeve, 2016, autonomy-supportive teaching)

Section E: This section relates to implications of your views on motivation on course design and teacher approach within this project.

1. What elements of the courses you teach do you consider motivating to your students? Why?

2. Which elements do you feel are less motivating or cause demotivation? Why?

3. How confident are you that you are usually able to motivate your students? 